\title{
Erosive characteristics and fluoride content of cola-type drinks.
}

Narges Omid ${ }^{1}$, Fatemeh Vida Zohoori ${ }^{2}$, Simon Kometa ${ }^{3}$, Anne Maguire*1

${ }^{1}$ Centre for Oral Health Research, School of Dental Sciences, Newcastle University, UK

${ }^{2}$ School of Health and Social Care, Teesside University, Middlesbrough, UK

${ }^{3}$ Research Collaborative Services, Newcastle University Information Technology, Newcastle University, UK

Running title: Erosive potential and fluoride concentration of cola-type drinks

Key words: Erosion; fluoride concentration; soft drinks; titratable acidity; $\mathrm{pH}$

\section{*Corresponding Author:}

Professor Anne Maguire

Centre for Oral Health Research,

School of Dental Sciences,

Newcastle University,

NE2 4BW, UK,

Email: anne.maguire@ncl.ac.uk 


\begin{abstract}
Aim: Excessive consumption of carbonated soft drinks is detrimental to general and oral health. This study determined endogenous $\mathrm{pH}$, titratable acidity (TA) and fluoride (F) ion concentration of cola-type drinks available in the UK. Subsidiary aims were to compare; i) endogenous $\mathrm{pH}$ and TA of drinks upon opening (T0) and after 20 minutes (T20); ii) endogenous $\mathrm{pH}, \mathrm{TA}$ and $\mathrm{F}$ ion concentration of diet $\mathrm{v}$ regular and plastic $\mathrm{v}$ canned drinks.
\end{abstract} Methods: Endogenous pH, TA (mls $0.1 \mathrm{M} \mathrm{NaOH})$ and $\mathrm{F}$ ion $(\mathrm{mg} / \mathrm{L})$ of 71 products measured using $\mathrm{pH}$ meter and F-ISE. A Wilcoxon Signed Ranks Test compared $\mathrm{pH}$ and TAs at T0 and T20; a Mann-Whitney U test compared $\mathrm{pH}$, TAs and F ion concentration for; a) regular v diet drinks; b) plastic v canned drinks.

Results: Mean $( \pm \mathrm{SD}) \mathrm{pH}$ for regular and diet drinks was $2.44 \pm 0.12$ and $2.83 \pm 0.33$ respectively ( $\mathrm{p}=0.001)$; mean $\mathrm{NaOH}(\mathrm{ml})$ to raise $\mathrm{pH}$ to 5.5 and 5.7 was $5.49 \pm 0.76$ and $6.40 \pm$ 0.78 (regular drinks); $5.17 \pm 1.03$ and $6.03 \pm 1.07$ (diet drinks). Diet $(\mathrm{p}=0.040)$ and regular $(\mathrm{p}=0.041)$ drinks had higher TA to $\mathrm{pH} 5.7$ at T0 compared with T20; at T20 regular drinks had higher TA to $\mathrm{pH} 5.5(\mathrm{p}=0.026)$ and $\mathrm{pH} 5.7(\mathrm{p}=0.030)$ than diet drinks. There was no difference in $\mathrm{F}$ ion concentration between regular $\mathrm{v}$ diet drinks $(\mathrm{p}=0.754)$ and no significant container effect.

Conclusion: Erosive characteristics were similar between manufacturers but higher erosive potentials were evident at $\mathrm{T} 0$ compared with 20 minutes later and for regular compared with diet drinks. F ion concentration of drinks was low. 


\section{Introduction}

Dental erosion is recognised as an important cause of tooth tissue loss in all age groups ${ }^{1}$ and is defined as a "surface dissolution of dental hard tissues in the absence of dental plaque" 2.

The significant growth in soft drinks consumption in recent decades has resulted in a market which is now very competitive as more generic drinks, including cola-type drinks, are produced by supermarkets at lower prices compared to proprietary drinks. Children start consuming soft drinks at an increasingly younger age and the volumes consumed increase through young adulthood ${ }^{3}$. The assessment of dental erosion in a group of 14 year old British children showed that over $80 \%$ consumed soft drinks on a regular basis ${ }^{4}$. In a review comparing data from the 1993 UK children's dental health (CDH) survey ${ }^{5}$, the National Diet and Nutrition Surveys (NDNS) of 1 1/2 - 41/2 year olds in 1992-3 ${ }^{6}$ and $4-18$ year olds in 1996-7 ${ }^{7}$, Nunn et al ${ }^{8}$ reported a trend towards a higher prevalence of dental erosion in children aged $3 \frac{1}{2}$ and $4 \frac{1}{2}$ years and in those who consumed carbonated drinks on most days. They also reported a greater prevalence of erosion in both primary and permanent incisors shown in the 1996-7 NDNS survey of 4-18 year olds compared with a similar age group in the 1993 UK CDH survey. Overall, $18 \%$ of the labial surfaces of primary incisors in 4-6-year-olds were affected with erosion in 1993, compared with $38 \%$ in $1996 / 7$ and the prevalence of erosion in permanent incisors of $11-14$ year olds was $11 \%$ in 1993 compared with $23 \%$ in $1996 / 7^{8}$. Limited information is available on $\mathrm{pH}$ and titratable acidity of proprietary brand cola- type carbonated drinks produced in the UK and these data are no longer current, while no information is currently available on generic brand cola-type drinks produced by UK supermarkets. 
The erosive characteristics of a beverage are linked to several factors including its endogenous $\mathrm{pH}$, the total acid content (titratable acidity) and the type of acid ( $\mathrm{pKa}$ ) it contains. In addition, length of exposure to acid and concentration of phosphate, calcium and fluoride $(\mathrm{F})$ in foods and drinks can have a modifying effect on the development of dental erosion ${ }^{9}$. A drink with higher titratable acidity will result in the dissolution of more apatite before neutral $\mathrm{pH}$ is approached and the dissolution is terminated. While some studies suggest that titratable acidity is a more important indicator than the endogenous $\mathrm{pH}$ value in determining the erosive potential of drinks ${ }^{10,11}$, in studies by Hemingway et al ${ }^{12}$ on a group of fruit juices, and by Jensdottir et al on soft drinks, ${ }^{13}$ the effect of endogenous $\mathrm{pH}$ was reported to be more important since endogenous $\mathrm{pH}$ only provides a measure of initial hydrogen ion concentration and gives no indication to the current and potential presence of dissociated acid ${ }^{3}$. In addition to these factors, it is unclear whether the type of drink; i.e. whether it is a "regular" sugars-containing beverage or a "diet" sugars-free alternative changes its erosive characteristics. Furthermore, information on the effect of container type (i.e. contained in a plastic bottle or aluminium can) on the erosive potential of these drinks is limited.

There is strong evidence that topical $\mathrm{F}$ use can strengthen teeth against erosive acid damage and high-concentration $\mathrm{F}$ agents and/or frequent applications of lower concentration $\mathrm{F}$, eg. fluoridated waters ${ }^{14}$ are considered potentially effective approaches in preventing dental erosion ${ }^{15}$. With recent trends towards increased consumption of carbonated soft drinks and juices as a substitute for healthier options such as optimally fluoridated tap waters, there is also a need to assess the impact of these drinks on the overall $\mathrm{F}$ exposure of children and information on the $\mathrm{F}$ ion content of commonly consumed products is required to make this assessment. Although the F ion concentration of soft drinks is primarily determined by the $\mathrm{F}$ ion concentration in water used to manufacture these products, no information is available on 
the actual resultant $\mathrm{F}$ ion content of these drinks which may constitute a significant proportion of daily fluid intake in some individuals.

This study aimed to determine the endogenous $\mathrm{pH}$, titratable acidity (to critical $\mathrm{pH}$ for enamel and dentine) and $\mathrm{F}$ ion concentration, of cola-type drinks. The subsidiary aims were firstly, to compare the endogenous $\mathrm{pH}$ and the titratable acidity (TA) of the drinks upon opening (T0) and after 20 minutes (T20), and secondly, to compare the endogenous $\mathrm{pH}$, titratable acidity and $\mathrm{F}$ ion concentration of diet compared with regular drinks, and plastic-bottle-contained compared with can-contained cola drinks. 


\section{Materials and Methods}

\section{Sourcing samples}

A list of all available cola-type drinks on the UK market was prepared by searching supermarkets' websites as well as visiting some of them directly. Based on the product and container types available for generic and proprietary drinks, 71 cola-type drink products from 9 different supermarket companies were identified for purchase.

Samples were purchased from different supermarkets in the north-east of England and stored at room temperature prior to analysis. For the purpose of $\mathrm{F}$ ion analysis, 3 different batch numbers for each product type and container were purchased which resulted in a total of 213 samples. All drinks were purchased over a two month period between February and April 2012. Information concerning brand name, flavour, sugars content, type of container and expiry dates was recorded.

To help determine the impact of sugars content (i.e. regular (sugars-containing) v diet (sugars-free) drinks) on erosive potential and $\mathrm{F}$ ion content, the drinks were divided into two broad categories of diet $(n=48)$ and regular $(n=23)$ drinks. Within each category the regular group comprised flavoured and classic drinks while the diet group included diet-flavoured, "Zero", caffeine-free, "Max" and no added sugar drinks.

Regarding packaging, three types of containers were identified, with plastic bottles $(65 \%$, $\mathrm{n}=46)$ and aluminium cans $(32 \%, \mathrm{n}=23)$ accounting for $97 \%$ of the 71 products analysed. The only drinks distributed in glass bottles $(\mathrm{n}=2)$ were regular and diet Coca-Cola products.

\section{Endogenous $\mathrm{pH}$}

At the start of each analysis session, the meter (model 720A, Orion, USA) and pH electrode (Model 68788 Thermo Orion, USA) was calibrated using standard buffers (Mettler Toledo, UK) at $\mathrm{pH} 2.0,4.0$ and 7.0. The manufacturer's reported precision for the $\mathrm{pH}$ electrode was 
\pm 0.01 . The electrode was then rinsed and placed into de-ionised water before starting $\mathrm{pH}$ measurements of the drinks, allowing the $\mathrm{pH}$ electrode to stabilise for between 2-3 minutes before each measurement was recorded. From the three batch numbered items purchased for each drink, one batch number was selected randomly and $50 \mathrm{ml}$ of the freshly opened drink was poured into a plastic beaker.

The $\mathrm{pH}$ of each drink sample was measured just after opening (T0). Plastic-bottled drinks were re-capped after initial opening while cans and glass bottles were left exposed after opening to simulate usual drinking conditions. A second $\mathrm{pH}$ reading was performed after 20 minutes (T20) with a second aliquot from the same sample. For each sample one $\mathrm{pH}$ measurement was performed at each time point.

\section{Titratable Acidity}

Fifty $\mathrm{ml}$ of each drink, kept at room temperature and for which the endogenous $\mathrm{pH}$ had been measured was titrated manually to $\mathrm{pH} 6$ by adding $0.1 \mathrm{M} \mathrm{NaOH}$ in $1 \mathrm{ml}$ increments with continuous stirring. The volumes of titrant needed to raise the sample $\mathrm{pH}$ to 5.5 and 5.7, (critical pHs for enamel and dentine dissolution respectively), were then calculated from the plotted volume against the $\mathrm{pH}$ curve.

After 20 minutes (T20), a second volume of $50 \mathrm{ml}$ of the same drink sample was poured from the container into the beaker and the same process of titration was undertaken. For each sample one titration was performed for each time point.

\section{F ion analysis}

For $\mathrm{F}$ ion analysis, equal volumes $(5 \mathrm{ml})$ of drink from each of the 3 batch numbered items within each product type and container type were taken and mixed together in a plastic beaker. Due to the large number of samples, three aliquots $(5 \mathrm{ml}$ each) of the mixed batches 
for each sample were taken and stored at $-20^{\circ} \mathrm{C}$ prior to $\mathrm{F}$ ion analysis until preparation of all samples had been completed.

The F ion concentration of each sample was measured in duplicate by a direct method using an F ion-selective electrode (F-ISE) (Model 9609, Thermo Orion, USA) coupled to a meter (Model 720A, Orion, USA) after sample buffering with Total Ionic Adjustment Buffer (TISAB III) ${ }^{16}$. The F-ISE was reported by the manufacturers to have a limit of detection of $\pm 0.02 \mu \mathrm{g} / \mathrm{ml}$ (Orion Plus F Electrode, Thermo Electron Corporation, USA). Ten percent of samples $(n=7)$ were re-analysed to confirm the reliability of the method.

\section{Statistical analysis}

The data were analysed using IBM SPSS Statistics software (Version 21 Chicago, IL, USA). Descriptive (summary) statistics were used to present endogenous $\mathrm{pH}$, TA (to $\mathrm{pH} 5.5$ and 5.7) at $\mathrm{T} 0$ and $\mathrm{T} 20$, and $\mathrm{F}$ concentration, according to sugars content and container type. Normality testing indicated that the data were not normally distributed and consequently a Wilcoxon Signed Ranks Test was performed to determine any statistically significant differences in endogenous $\mathrm{pH}$ and TAs at T0 and T20. A Mann-Whitney U test was used to determine whether sugars content (regular v diet) or container type (plastic v can) had any effect on these same variables. A $p$ value less than 0.05 was considered to be statistically significant. 


\section{Results}

\section{Endogenous $\mathrm{pH}$}

Table 1 shows the mean $\pm \mathrm{SD}$ endogenous $\mathrm{pH}$ of drinks based on their sugars content at $\mathrm{T} 0$ and after 20 minutes (T20) and for all brands. Overall, there was no difference in $\mathrm{pH}$ between opening and after 20 minutes for the 23 regular drinks with a mean $\mathrm{pH}$ at $\mathrm{T} 0$ and $\mathrm{T} 20$ of 2.43 , while for diet drinks it was 2.85. Marks and Spencer regular cola drinks had the lowest mean (SD) endogenous $\mathrm{pH}$ for all drinks $(2.10 \pm 0.00)$ at both $\mathrm{T} 0$ and $\mathrm{T} 20$ time points, while ALDI diet cola drinks had the highest $\mathrm{pH}$ overall $(3.30 \pm 0.20)$, measured at T20.

Based on container type (Table 2), the lowest mean (SD) endogenous $\mathrm{pH}(2.35 \pm 0.35)$ was observed for plastic bottles from Marks and Spencer at T0 and T20, the highest mean endogenous $\mathrm{pH}$ being recorded for ALDI canned colas at T0 (3.20 \pm 0.00$)$.

Table 3 shows the results of the Wilcoxon Signed Rank Test which compared related samples between opening (T0) and 20 minutes after opening (T20). For the diet drinks there was no statistically significant difference in the endogenous $\mathrm{pH}$ values between the two time points $[\mathrm{Z}$-score $=-0.13, \mathrm{p}=0.894]$ and this was also true for regular drinks $[\mathrm{Z}$-score $=-0.74, \mathrm{p}=0.458]$.

To consider the effect of sugars content and container type at a given time point a MannWhitney U Test was used. As Table 4 shows, there was a statistically significantly higher endogenous $\mathrm{pH}$ in diet drinks compared with regular drinks at T0 and T20 [Mann-Whitney $\mathrm{U}=149, \mathrm{p}=0.001$ and Mann-Whitney $\mathrm{U}=132, \mathrm{p}=0.001$ respectively]. There was no significant difference in the endogenous $\mathrm{pH}$ values between can and plastic bottles at T0 or T20 (Table $5)$. 


\section{Titratable acidity}

When the TA of 6 drink samples was measured 3 times during the preparatory phase of the study, there was an average of $3 \%$ difference in TA at T0 and T20 between the replicates, indicating that the method was reproducible. The mean (SD) volumes (ml) of $0.1 \mathrm{M} \mathrm{NaOH}$ required to raise the $\mathrm{pH}$ of $50 \mathrm{ml}$ of each drink sample to 5.5 and 5.7 at $\mathrm{T} 0$ and $\mathrm{T} 20$ based on their sugars content and container type are presented in Tables 1 and 2 . The 23 regular drinks had a mean TA (to $\mathrm{pH} 5.5$ ) of $5.49 \pm 0.76 \mathrm{ml}$ at $\mathrm{T} 0$ and $5.38 \pm 0.72 \mathrm{ml}$ at $\mathrm{T} 20$, while the equivalent recordings were $5.27 \pm 0.96$ and $5.18 \pm 0.99 \mathrm{ml}$ for the 48 diet drinks. The greatest TA recorded for raising the $\mathrm{pH}$ to 5.5 was for Marks and Spencer and Morrison regular colas $(7.00 \mathrm{ml}$ of $0.1 \mathrm{M} \mathrm{NaOH})$; the Marks and Spencer regular cola also had the greatest TA to $\mathrm{pH}$ $5.7(8.00 \pm 0.00 \mathrm{ml}$ at T0 and T20). As Table 2 shows, it was the Morrison cola in a plastic bottle which showed the highest TA to $\mathrm{pH} 5.5(6.03 \pm 1.77 \mathrm{ml})$ at $\mathrm{T} 0$, while to raise the $\mathrm{pH}$ to 5.7 took a mean of $6.92 \pm 0.59 \mathrm{ml}$ of $\mathrm{NaOH}$ for the Tesco plastic-contained colas at T0. For both regular and diet drinks, the TA (to $\mathrm{pH}$ 5.7) was statistically significantly lower 20 minutes after opening compared with T0 $(\mathrm{p}<0.05)$ (Table 3$)$.

When the effect of sugars content and container type on titratable acidity was considered, as Table 4 shows, regular drinks had a statistically significantly higher TA (to $\mathrm{pH} 5.5$ and 5.7) compared with diet drinks at T20. [Mann-Whitney $U=372, p=0.026$ and Mann-Whitney $\mathrm{U}=376, \mathrm{p}=0.030$ respectively]. However there was no significant difference in the TA values between can and plastic bottles at T0 or T20 (Table 5)

\section{F ion concentration $(\mathrm{mg} / \mathrm{L})$}

The $\%$ difference in $\mathrm{F}$ ion concentration between test- to re-test for $10 \%$ of the samples was $5 \%$ which indicated an acceptable level of reliability in measurement. The F ion concentrations of drinks (mg/L) based on their sugars content (i.e. regular or diet) and 
container type (i.e. plastic bottle or metallic can) are presented in Tables 1 and 2 respectively. The overall mean $\mathrm{F}$ ion concentration for both regular and diet drinks was $0.09 \pm 0.11 \mathrm{mg} / \mathrm{L}$ with only $3(4 \%)$ of the 71 drinks having a $F$ ion concentration $\geq 0.3 \mathrm{mgF} / \mathrm{L}$. The highest $\mathrm{F}$ ion concentration was found in a regular Pepsi cola group (mean $0.24 \pm 0.14 \mathrm{mg} / \mathrm{L}$ ); the lowest mean being $0.02 \mathrm{mg} / \mathrm{L}$ and found in 3 regular cola groups (ALDI, Morrison and Tesco) and 2 diet cola groups (Co-op and Tesco). Based on container type, Pepsi drinks distributed in cans showed the highest $\mathrm{F}$ ion concentration (mean $0.28 \mathrm{mg} / \mathrm{L}$ ) followed by Coca-Cola drinks distributed in glass $(0.26 \mathrm{mg} / \mathrm{L})$, while the mean $(\mathrm{SD}) \mathrm{F}$ ion concentrations of Coca-Cola drinks in cans $(\mathrm{n}=6)$ and plastic bottles $(\mathrm{n}=7)$ were $0.08(0.04) \mathrm{mg} / \mathrm{L}$ and $0.06(0.04) \mathrm{mg} / \mathrm{L}$ respectively.

No statistically significant differences in $\mathrm{F}$ ion concentration were found between either regular and diet type drinks $(p=0.754)$ or between plastic bottle and canned drinks $(p=0.726)$ (Tables 4 and 5). 


\section{Discussion}

This study measured the endogenous $\mathrm{pH}$ of 71 cola drinks at baseline (upon opening at $\mathrm{T} 0$ ) and 20 minutes after opening. The 20 minute time interval was selected to simulate average drinking time. Endogenous $\mathrm{pH}$ and TA for Coca-Cola and Pepsi products have been reported in other studies ${ }^{17,18}$, however, this is the first study to consider the erosive characteristics of all cola-type drinks available in the UK market. All drinks had an endogenous $\mathrm{pH}$ below the critical $\mathrm{pH}(5.5){ }^{19}$ for enamel dissolution. The inherent acidity of these drinks is mainly due to the addition of acids during their manufacturing process to improve their organoleptic properties since acidity is a key factor to stimulate taste and counteract sweetness. The strength of an acid is usually described by its $\mathrm{pK}_{\mathrm{a}}$ values - negative logarithms of $\mathrm{K}_{\mathrm{a}}$ values, i.e. their acid dissociation constants. According to the manufacturer's labelling, phosphoric acid (with $\mathrm{pK}_{\mathrm{a}}$ values of $2.15,7.20$, and 12.35 - one for each of the hydrogen ions reversibly bound to the phosphate ion) was the main acid included in both regular and diet type drinks. However, citric acid (with $\mathrm{pK}_{\mathrm{a}}$ values of $3.08,4.74$ and 6.42 ) was additionally included in regular ASDA and Marks \& Spencer drinks. Phosphoric acid and citric acid were included in almost all the diet type drinks except for those from Tesco and the Co-op. Citric acid has been highlighted as having a particularly detrimental effect on dental enamel and can cause severe demineralisation due to its ability to chelate minerals of apatite such as calcium ${ }^{20,21}$, while malic acid, present in the diet cola drinks produced by ASDA, Co-op and Marks \& Spencer, is slightly less detrimental ${ }^{22}$. In a study by Edwards and co-workers, ${ }^{23}$ the higher TA for fruit juices compared with other carbonated drinks was reported to be due to citric acids derived from the fruit. However, in the current study, despite the presence of additional exogenous acids in the diet drink group their endogenous $\mathrm{pH}$ was higher and their TAs were lower compared with the regular group of drinks. 
It is important that total $\mathrm{TA}^{23,24}$ and the relative strength of the acid which indicates how easily the acid will "actively" give up free $\mathrm{H}^{+}$ions $\left(\mathrm{pK}_{\mathrm{a}}\right)^{25}$ is considered when determining the erosive potential of drinks. While TA is responsible for maintaining the $\mathrm{H}^{+}$concentration available for the interaction with the tooth surface ${ }^{10,22}$, its importance in the clinically erosive situation is influenced by conditions such as exposure time and the ratio of the volume of eroding solution to the area of exposed tooth surface ${ }^{18}$. The in vitro conditions in which the drinks were tested in this study will impact on the clinical relevance of the results since biological factors such as salivary flow rate and its buffering capacity, as well as individual's drinking habits, are important modifiers in the erosion process clinically. However this study provides a simple method for identifying potentially erosive drinks in vitro and helps to inform clinicians and their patients when potentially erosive products are being discussed as part of dietary analysis and advice.

This study also investigated any potential differences in TA of plastic bottled versus canned drinks following opening since bottled drinks can be recapped while canned drinks are left exposed after opening. The decrease in TA after 20 minutes was found to be similar between plastic bottles (recapped) and cans (exposed) contained drinks. In contrast, for a group of UK flavoured sparkling waters the decrease in TA after 30 minutes exposure to air was reported to range from $26-48 \%{ }^{26}$. According to the authors, this difference could be due to a variation in the degree of carbonation introduced during production between cola drinks and flavoured waters.

As one of the main aims of this study, $\mathrm{F}$ ion concentrations of drinks were also measured. Several studies have previously measured F ion concentrations of carbonated drinks, either in relation to measuring $\mathrm{F}$ exposure ${ }^{27,28}$, or in determining whether the $\mathrm{F}$ can mitigate against dental erosion ${ }^{17,29}$ and have reported a wide range in $\mathrm{F}$ ion concentrations from $0.02 \mathrm{mg} \mathrm{F} / \mathrm{L}$ to $1.62 \mathrm{mg} \mathrm{F} / \mathrm{L}$. However, no study has reported on the $\mathrm{F}$ ion concentration of the different 
types of cola drinks available in the UK market. Overall, the median (range) F ion concentration of drinks in the present study at $0.03(0.01-0.60) \mathrm{mg} / \mathrm{L}$ was lower than the 0.72 $(0.02-1.28) \mathrm{mg} / \mathrm{L}$ and $0.91(0.1-1.62) \mathrm{mg} / \mathrm{L}$ reported for the cola drinks from the US ${ }^{27}$ and Mexico ${ }^{28}$ respectively. In both those studies the wide range in $\mathrm{F}$ ion concentration was attributed to the variation in the $\mathrm{F}$ ion concentration of water sources used in the production sites which could also explain the range in values found in the present study. The substantial difference in the $\mathrm{F}$ ion concentration of identical products from different sites for the US study also highlights that variation in $\mathrm{F}$ ion concentration of water sources appears to be the main determinant of any variation seen in soft drink product $\mathrm{F}$ ion concentrations.

The current study found no statistically significant difference between $\mathrm{F}$ ion concentrations of diet versus regular drinks which is consistent with the results reported by Heilman and coworkers ${ }^{27}$ in the US.

Although between-container differences in $\mathrm{F}$ ion concentration have been reported previously ${ }^{28}$, the present study found similar F ion concentrations for drinks sold in cans and in plastic bottles (median: $0.03 \mathrm{mg} / \mathrm{L}$ ). While no significant difference was reported for $\mathrm{F}$ ion concentrations of drinks sold in glass and cans in the work by Heilman et al., ${ }^{27}$ in the US, the F ion concentration of canned Mexican cola drinks was reported to be higher $(0.74 \mathrm{mg} / \mathrm{L})$ than those drinks sold in plastic $(0.37 \mathrm{mg} / \mathrm{L})$ and glass containers $(0.34 \mathrm{mg} / \mathrm{L})^{28}$. This may reflect the use of different containers in different parts of a country in which the $\mathrm{F}$ ion concentrations of the manufacturers' supply waters also differ.

Furthermore, the current study found that only the Coca-Cola Company produced drinks in glass containers. In laboratories, F solutions are not normally stored in glass containers as F ion has an affinity for glass, reducing the $\mathrm{F}$ ion concentration of its contents ${ }^{28}$. Despite this high affinity of $\mathrm{F}$ ion for glass the median $\mathrm{F}$ ion concentration of Coca-Cola drinks in glass containers was higher $(0.26 \mathrm{mg} / \mathrm{L})$ compared with the $0.1 \mathrm{mg} / \mathrm{L}$ found for Coca-Cola drinks in 
cans and plastic bottles, suggesting that higher $\mathrm{F}$ ion concentration waters may have been used for the production of these drinks.

Overall, there was no difference in the $\mathrm{F}$ ion concentration of regular versus diet cola drinks, nor between plastic bottled and canned drinks. It is the water used in production of cola drinks which appears to be the main determinant of their $\mathrm{F}$ ion concentration. Overall, the $\mathrm{F}$ ion concentration of drinks in this study was low (Mean (SD) $0.09(0.11) \mathrm{mgF} / \mathrm{L}$ ), although it did appear to vary with water sources used in their production. Unfortunately, soft drinks may comprise a significant proportion of an individual's fluid intake and detract from the general and oral health benefits associated with drinking water. It is important for health professionals and consumers to be aware of this when supporting their patients to make good dietary choices. The inclusion of general and oral health information covering dental caries and erosion risk as well as including the $\mathrm{F}$ ion content on soft drinks packaging and labels would facilitate this.

The cola-type drink products tested in this study were representative of those available in the UK market. Their erosive characteristics were broadly similar between manufacturers but with significantly higher erosive potentials evident upon opening compared with 20 minutes later and for regular drinks compared with diet drinks. The $\mathrm{F}$ ion concentration of drinks was low; $96 \%$ of the 71 products contained $<0.3 \mathrm{mgF} / \mathrm{L}$, most probably due to the $\mathrm{F}$ ion concentration of water used by manufacturers to prepare them. 


\section{Acknowledgements}

The present study was partially supported by grants from the Borrow Foundation and The

Organix Foundation. The views expressed in this paper are those of the authors and not those of the funding bodies. 


\section{References}

1. Nunn JH. Prevalence of dental erosion and the implications for oral health. Eur J Oral Sci 1996; 104: 156-161.

2. Lussi A, Carvalho TS. Erosive tooth wear: A multifactorial condition of growing concern and increasing knowledge. In Lussi A, Ganss C, (ed). Erosive Tooth Wear: From Diagnosis to Therapy. Basel: Karger; 2014. p.1-15.

3. Tahmassebi JF, Duggal MS, Malik-Kotru G, Curzon MEJ. Soft drinks and dental health: A review of the current literature. $J$ Dent 2006; 34: 2-11.

4. Al-Dlaigan YH, Shaw L, Smith A. Dental erosion in a group of British 14-year-old school children. Part II: Influence of dietary intake. Br Dent J 2001; 190: 258-261.

5. O'Brien M. Children's dental health in the United Kingdom 1993. London: Office of Population Censuses and Surveys., 1994.

6. Hinds K, Gregory JR. National Diet and Nutrition Survey: Children Aged $1_{1 / 2}$ to $4_{1 / 2}$ Years, London: Her Majesty's Stationery Office., 1995

7. Gregory J, Lowe S, Bates C, Prentice A, Jackson L, Smithers G, Wenlock R, Farron M. National Diet and Nutrition Survey: children aged $1_{1 / 2}$ to $4_{1 / 2}$ years. Report of the diet and nutrition survey. London: The Stationary Office., 2000

8. Nunn JH, Gordon PH, Morris A.J, Walker A. Dental erosion-changing prevalence? A review of British National childrens' surveys. Int J Paed Dent 2003; 13: 98-105.

9. Zero DT. Etiology of dental erosion-extrinsic factors. Eur J Oral Sci 1996; 104: 162-177.

10. Grobler SR, Jenkins GN, Kotze D. The effects of the composition and method of drinking of soft drinks on plaque pH. Br Dent J 1985; 158: 293-296.

11. Shaw L, Smith AJ. Dental erosion - the problem and some practical solutions. Br Dent J 1999; 186: 115-118.

12. Hemingway CA, Parker DM, Addy M, Barbour ME. Erosion of enamel by noncarbonated soft drinks with and without toothbrushing abrasion. Br Dent J 2006; 201: 447450 .

13. Jensdottir T, Bardow A, Holbrook P. Properties and modification of soft drinks in relation to their erosive potential in vitro. J Dent $2005 ; 33: 569-575$

14. Bardsley PF, Taylor S, Milosevic A. Epidemiological studies of tooth wear and dental erosion in 14-year-old children in north West England. Part 1: The relationship between water fluoridation and social deprivation. . Br Dent J 2004; 197: 413-416. 
15. Magalhaes AC, Wiegand A, Rios D Buzalaf MAR, Lussi A. Fluoride in dental erosion. In Buzaluff MAR editor. Fluoride and the Oral Environment. Basel: Karger; 2011. P.158170.

16. Martínez-Mier EA, Cury J.A., Heilman J.R. et al. Development of gold standard ionselective electrode-based methods for fluoride analysis Caries Res 2011; 45: 3-12.

17. de Carvalho Sales-Peres SH, Magalhães AC, Machado MAAM, Buzalaf MAR. Evaluation of the erosive potential of soft drinks. Eur J Dent 2007; 1: 10-13.

18. Lussi A, Megert B, Peter Shellis R, Wang X. Analysis of the erosive effect of different dietary substances and medications. Br J Nutr 2012; 107: 252-262.

19. Barron, RP. Carmichael, RP. Marcon, MA. Sandor, GK. Dental erosion in gastroesophageal reflux disease. J Can Dent Assoc 2003; 69: 84-89.

20. Lussi A, Jaeggi T, Jaeggi-Schärer S. Prediction of the erosive potential of some beverages. Caries Res 1995; 29: 349-354.

21. Attin T, Koidl U, Buchalla W, Schaller HG, Kielbassa AM, Hellwig E. Correlation of microhardness and wear in differently eroded bovine dental enamel. Arch Oral Biol 1997; 42: 243-250.

22. Grenby TH, Phillips A, Desai T, Mistry M. Laboratory studies of the dental properties of soft drinks. Br J Nutr 1989; 62: 451-464.

23. Edwards M, Creanor SL, Foye RH, Gilmour WH. Buffering capacities of soft drinks: the potential influence on dental erosion. J Oral Rehab 1999; 26: 923-927.

24. Meurman JH, Gate JM. Pathogenesis and modifying factors of dental erosion. Eu J Oral Sci 1996; 104: 199-206.

25. Rugg-Gunn AJ, Maguire A, Gordon PH, McCabe JF, Stephenson G. Comparison of erosion of dental enamel by four drinks using an intra-oral applicance. Caries Res 1998; 32: 337-343.

26. Brown CJ, Smith GAY, Shaw L, Parry J, Smith AJ The erosive potential of flavoured sparkling water drinks. Int J Paed Dent 2007; 17: 86-91.

27. Heilman JR, Kiritsy MC, Levy SM, Wefel JS. Assessing fluoride levels of carbonated soft drinks. J Am Dent Assoc 1999; 130: 1593-1599.

28. Jimenez-Farfan MD, Hernandez-Guerrero JC, Loyola-Rodriguez JP, Ledesma-Montes C. Fluoride content in bottled waters, juices and carbonated soft drinks in Mexico City, Mexico. Int J Paed Dent 2004; 14: 260-266.

29. Larsen M, Nyvad B. Enamel erosion by some soft drinks and orange juices relative to their $\mathrm{pH}$, buffering effect and contents of calcium phosphate. Caries Res 1999; 33: 81-87. 


\section{Table Legends}

Table 1 Mean (SD) endogenous $\mathrm{pH}$, titratable acidity (TA -mls of $0.1 \mathrm{M} \mathrm{NaOH}$ ) to $\mathrm{pH} 5.5$ and 5.7 at opening (T0) and 20 minutes after opening (T20) and $\mathrm{F}$ ion concentration (mg/L) of drinks based on brand and sugars content (Regular or Diet).

Table 2 Mean (SD) endogenous $\mathrm{pH}$, titratable acidity (TA -mls of $0.1 \mathrm{M} \mathrm{NaOH}$ ) to $\mathrm{pH} 5.5$ and 5.7 at opening (T0) and 20 minutes after opening (T20) and $\mathrm{F}$ ion concentration $(\mathrm{mg} / \mathrm{L})$ of drinks based on brand and container type.

Table 3 Comparison of endogenous $\mathrm{pH}$ and titratable acidity (TA -mls of $0.1 \mathrm{M} \mathrm{NaOH}$ ) to $\mathrm{pH}$ 5.5.and 5.7 upon opening (T0) and 20 minutes after opening (T20).

Table 4 Comparison of endogenous $\mathrm{pH}$, titratable acidity (TA - $\mathrm{ml}$ of $0.1 \mathrm{M} \mathrm{NaOH})$ to $\mathrm{pH} 5.5$ and 5.7 and $\mathrm{F}$ ion concentration $(\mathrm{mg} / \mathrm{L})$ of drinks based on their sugars content (Diet $\mathrm{V}$ Regular).

Table 5 Comparison of endogenous $\mathrm{pH}$, titratable acidity (TA - $\mathrm{ml}$ of $0.1 \mathrm{M} \mathrm{NaOH}$ ) to $\mathrm{pH} 5.5$ and 5.7 and $\mathrm{F}$ concentration $(\mathrm{mg} / \mathrm{L})$ of drinks based on container type (can v plastic bottle). 
Table 1. Mean (SD) endogenous pH, titratable acidity (TA - mls of $0.1 \mathrm{M}$ NaOH) to pH 5.5 and 5.7 at opening (T0) and 20 minutes after opening (T20) and F ion concentration $(\mathrm{mg} / \mathrm{L})$ of drinks based on brand and sugars content (Regular or Diet)

\begin{tabular}{|c|c|c|c|c|c|c|c|}
\hline \multirow{3}{*}{$\begin{array}{l}\text { Drinks (number of } \\
\text { products) }\end{array}$} & \multicolumn{7}{|c|}{ Mean (SD) } \\
\hline & \multicolumn{2}{|c|}{ Endogenous $\mathrm{pH}$} & \multicolumn{2}{|c|}{ TA $(\mathrm{ml})$ to $\mathrm{pH} 5.5$} & \multicolumn{2}{|c|}{ TA $(\mathrm{ml})$ to $\mathrm{pH} 5.7$} & \multirow{2}{*}{$\begin{array}{l}\text { F ion concentration } \\
(\mathrm{mg} / \mathrm{L})\end{array}$} \\
\hline & T0 & $\mathrm{T} 20$ & T0 & $\mathrm{T} 20$ & T0 & $\mathrm{T} 20$ & \\
\hline \multicolumn{8}{|l|}{ Regular } \\
\hline ALDI $(n=1)$ & $2.30(0.00)$ & $2.30(0.00)$ & $5.50(0.00)$ & $5.50(0.00)$ & $6.50(0.00)$ & $6.50(0.00)$ & $0.02(0.00)$ \\
\hline ASDA $(n=4)$ & $2.53(0.05)$ & $2.55(0.13)$ & $5.63(0.85)$ & $5.21(0.63)$ & $6.75(0.87)$ & $6.13(0.63)$ & $0.14(0.13)$ \\
\hline Co-op $(\mathrm{n}=1)$ & $2.30(0.00)$ & $2.40(0.00)$ & $5.33(0.00)$ & $5.66(0.00)$ & $6.00(0.00)$ & $6.50(0.00)$ & $0.03(0.00)$ \\
\hline Coca-Cola $(\mathrm{n}=5)$ & $2.42(0.04)$ & $2.40(0.10)$ & $5.00(0.00)$ & $5.02(0.48)$ & $5.93(0.15)$ & $5.78(0.65)$ & $0.09(0.08)$ \\
\hline Marks \& Spencer $(\mathrm{n}=1)$ & $2.10(0.00)$ & $2.10(0.00)$ & $7.00(0.00)$ & $7.00(0.00)$ & $8.00(0.00)$ & $8.00(0.00)$ & $0.20(0.00)$ \\
\hline Morrison $(n=1)$ & $2.30(0.00)$ & $2.30(0.00)$ & $7.00(0.00)$ & $6.00(0.00)$ & $7.66(0.00)$ & $7.00(0.00)$ & $0.02(0.00)$ \\
\hline Pepsi $(\mathrm{n}=2)$ & $2.50(0.00)$ & $2.40(0.14)$ & $4.66(0.00)$ & $4.66(0.00)$ & $5.50(0.00)$ & $5.50(0.00)$ & $0.24(0.14)$ \\
\hline Sainsbury's $(\mathrm{n}=4)$ & $2.55(0.06)$ & $2.48(0.13)$ & $5.33(0.38)$ & $5.15(0.34)$ & $6.17(0.41)$ & $5.92(0.44)$ & $0.03(0.01)$ \\
\hline Tesco $(n=4)$ & $2.45(0.10)$ & $2.48(0.10)$ & $5.83(0.87)$ & $5.93(0.92)$ & $6.67(0.93)$ & $6.54(0.93)$ & $0.02(0.01)$ \\
\hline All $(n=23)$ & $2.44(0.12)$ & $2.43(0.14)$ & $5.49(0.76)$ & $5.38(0.72)$ & $6.40(0.78)$ & $6.18(0.76)$ & $0.08(0.10)$ \\
\hline \multicolumn{8}{|l|}{ Diet } \\
\hline ALDI $(n=4)$ & $3.23(0.21)$ & $3.28(0.22)$ & $4.08(0.17)$ & $4.00(0.00)$ & $5.00(0.00)$ & $5.00(0.00)$ & $0.03(0.01)$ \\
\hline ASDA (n=9) & $2.71(0.09)$ & $2.68(0.08)$ & $5.11(0.61)$ & $5.14(1.08)$ & $5.92(1.12)$ & $5.92(1.12)$ & $0.16(0.13)$ \\
\hline Co-op $(n=2)$ & $2.45(0.07)$ & $2.55(0.07)$ & $5.21(0.77)$ & $4.97(0.90)$ & $5.63(0.88)$ & $5.63(0.88)$ & $0.02(0.00)$ \\
\hline Coca-Cola $(\mathrm{n}=10)$ & $3.06(0.11)$ & $3.03(0.12)$ & $5.52(1.46)$ & $5.43(1.44)$ & $6.18(1.44)$ & $6.18(1.44)$ & $0.10(0.08)$ \\
\hline Marks \& Spencer $(\mathrm{n}=1)$ & $2.60(0.00)$ & $2.60(0.00)$ & $5.00(0.00)$ & $5.00(0.00)$ & $5.66(0.00)$ & $5.66(0.00)$ & $0.21(0.00)$ \\
\hline Morrison $(\mathrm{n}=4)$ & $2.43(0.34)$ & $2.40(0.35)$ & $5.79(1.94)$ & $5.90(2.08)$ & $6.69(2.17)$ & $6.69(2.17)$ & $0.03(0.01)$ \\
\hline Pepsi ( $\mathrm{n}=5)$ & $3.12(0.35)$ & $3.06(0.34)$ & $5.20(0.30)$ & $5.06(0.36)$ & $5.97(0.42)$ & $5.97(0.42)$ & $0.22(0.21)$ \\
\hline Sainsbury's (n=7) & $2.53(0.17)$ & $2.99(1.17)$ & $5.05(0.85)$ & $4.90(0.60)$ & $5.56(0.74)$ & $5.56(0.74)$ & $0.05(0.07)$ \\
\hline Tesco $(n=6)$ & $2.93(0.23)$ & $2.97(0.20)$ & $5.14(0.87)$ & $4.89(0.66)$ & $5.72(0.80)$ & $5.72(0.80)$ & $0.02(0.01)$ \\
\hline All $(n=48)$ & $2.83(0.33)$ & $2.89(0.51)$ & $5.17(1.03)$ & $5.08(1.09)$ & $6.03(1.07)$ & $5.87(1.12)$ & $0.09(0.12)$ \\
\hline All products $(n=71)$ & $2.71(0.33)$ & $2.74(0.48)$ & $5.27(0.96)$ & $5.18(0.99)$ & $6.15(0.99)$ & $5.97(1.02)$ & $0.09(0.11)$ \\
\hline
\end{tabular}


Table 2. Mean (SD) endogenous pH, titratable acidity (TA - mls of $0.1 \mathrm{M}$ NaOH) to pH 5.5 and 5.7 at opening (T0) and 20 minutes after opening (T20) and F ion concentration (mg/L) of drinks based on brand and container type

\begin{tabular}{|c|c|c|c|c|c|c|c|}
\hline \multirow{3}{*}{$\begin{array}{l}\text { Container type (number } \\
\text { of products) }\end{array}$} & \multicolumn{7}{|c|}{ Mean (SD) } \\
\hline & \multicolumn{2}{|c|}{ Endogenous pH } & \multicolumn{2}{|c|}{ TA $(\mathrm{ml})$ to $\mathrm{pH} 5.5$} & \multicolumn{2}{|c|}{ TA $(\mathrm{ml})$ to $\mathrm{pH} 5.7$} & \multirow{2}{*}{$\begin{array}{l}\text { F ion concentration } \\
(\mathrm{mg} / \mathrm{L})\end{array}$} \\
\hline & $\mathrm{T} 0$ & $\mathrm{~T} 20$ & T0 & T20 & T0 & T20 & \\
\hline \multicolumn{8}{|l|}{ Can } \\
\hline ALDI $(n=2)$ & $3.20(0.00)$ & $3.15(0.07)$ & $4.00(0.00)$ & $4.00(0.00)$ & $5.00(0.00)$ & $5.00(0.00)$ & $0.04(0.01)$ \\
\hline ASDA $(n=5)$ & $2.66(0.11)$ & $2.68(0.13)$ & $5.13(1.06)$ & $5.13(1.06)$ & $6.17(0.80)$ & $6.07(1.11)$ & $0.03(0.00)$ \\
\hline Coca-Cola $(\mathrm{n}=6)$ & $2.86(0.37)$ & $2.82(0.38)$ & $5.39(1.31)$ & $5.36(1.35)$ & $6.22(1.41)$ & $6.11(1.35)$ & $0.08(0.04)$ \\
\hline Pepsi $(n=3)$ & $2.96(0.50)$ & $2.93(0.40)$ & $4.99(0.34)$ & $4.77(0.19)$ & $5.83(0.29)$ & $5.61(0.35)$ & $0.28(0.28)$ \\
\hline Sainsbury's $(\mathrm{n}=5)$ & $2.60(0.10)$ & $3.18(1.36)$ & $4.79(0.65)$ & $4.83(0.50)$ & $5.63(0.77)$ & $5.56(0.62)$ & $0.03(0.00)$ \\
\hline $\operatorname{Tesco}(n=2)$ & $2.75(0.49)$ & $2.75(0.49)$ & $6.00(0.71)$ & $5.66(1.41)$ & $6.92(0.59)$ & $6.33(1.41)$ & $0.01(0.00)$ \\
\hline All $(n=23)$ & $2.79(0.32)$ & $2.90(0.66)$ & $5.09(0.92)$ & $5.03(0.97)$ & $5.98(0.96)$ & $5.84(0.97)$ & $0.07(0.12)$ \\
\hline \multicolumn{8}{|l|}{ Plastic bottles } \\
\hline $\operatorname{ALDI}(n=3)$ & $2.93(0.60)$ & $3.03(0.66)$ & $4.61(0.79)$ & $4.50(0.87)$ & $5.50(0.87)$ & $5.50(0.87)$ & $0.02(0.00)$ \\
\hline ASDA $(n=8)$ & $2.65(0.13)$ & $2.61(0.09)$ & $5.35(0.68)$ & $5.18(0.92)$ & $6.23(0.88)$ & $5.94(0.96)$ & $0.23(0.09)$ \\
\hline Co-op $(n=3)$ & $2.40(0.10)$ & $2.50(0.10)$ & $5.25(0.55)$ & $5.19(0.75)$ & $5.89(0.51)$ & $5.92(0.80)$ & $0.02(0.01)$ \\
\hline Coca-Cola $(\mathrm{n}=7)$ & $2.84(0.28)$ & $2.81(0.29)$ & $5.55(1.25)$ & $5.52(1.19)$ & $6.48(1.18)$ & $6.33(1.19)$ & $0.06(0.04)$ \\
\hline Marks \& Spencer $(n=2)$ & $2.35(0.35)$ & $2.35(0.35)$ & $6.00(1.41)$ & $6.00(1.41)$ & $6.75(1.77)$ & $6.83(1.65)$ & $0.21(0.01)$ \\
\hline Morrison $(n=5)$ & $2.40(0.30)$ & $2.38(0.30)$ & $6.03(1.77)$ & $5.92(1.79)$ & $6.79(1.85)$ & $6.75(1.89)$ & $0.02(0.01)$ \\
\hline Pepsi $(n=4)$ & $2.93(0.42)$ & $2.83(0.49)$ & $5.08(0.42)$ & $5.08(0.42)$ & $6.04(0.67)$ & $6.00(0.41)$ & $0.19(0.10)$ \\
\hline Sainsbury's (n=6) & $2.48(0.15)$ & $2.48(0.20)$ & $5.44(0.66)$ & $5.12(0.53)$ & $6.25(0.70)$ & $5.79(0.71)$ & $0.05(0.07)$ \\
\hline Tesco $(n=8)$ & $2.74(0.29)$ & $2.78(0.28)$ & $5.27(0.91)$ & $5.22(0.84)$ & $6.17(0.92)$ & $5.97(0.87)$ & $0.02(0.00)$ \\
\hline All $(n=46)$ & $2.66(0.32)$ & $2.66(0.34)$ & $5.40(0.98)$ & $5.30(0.99)$ & $6.26(1.02)$ & $6.09(1.04)$ & $0.09(0.10)$ \\
\hline \multicolumn{8}{|l|}{ Glass } \\
\hline Coca-Cola $(n=2)$ & $2.80(0.57)$ & $2.85(0.49)$ & $4.50(0.71)$ & $4.30(0.06)$ & $5.50(0.71)$ & $4.88(0.18)$ & $0.26(0.06)$ \\
\hline All containers $(n=71)$ & $2.71(0.33)$ & $2.74(0.48)$ & $5.27(0.96)$ & $5.18(0.99)$ & $6.15(0.99)$ & $5.97(1.02)$ & $0.09(0.11)$ \\
\hline
\end{tabular}


Table 3. Comparison of endogenous $\mathrm{pH}$ and titratable acidity (TA - mls of $0.1 \mathrm{M} \mathrm{NaOH}$ ) to pH 5.5.and 5.7 upon opening (T0) and 20 minutes after opening (T20)

\begin{tabular}{|c|c|c|c|c|c|c|}
\hline $\begin{array}{l}\text { Product } \\
\text { Type }\end{array}$ & Comparisons & Ranks & $\mathbf{N}$ & $\begin{array}{l}\text { Mean } \\
\text { Rank } \\
\end{array}$ & $\begin{array}{l}\text { Z- } \\
\text { score }\end{array}$ & $\begin{array}{l}\mathbf{p} \\
\text { value }\end{array}$ \\
\hline \multirow{9}{*}{$\begin{array}{l}\text { Diet } \\
(n=48)\end{array}$} & \multirow{3}{*}{ Endogenous $\mathrm{pH}$ at T20 - Endogenous $\mathrm{pH}$ T0 } & Negative & 15 & 15.90 & \multirow{3}{*}{-0.133} & \multirow{3}{*}{0.894} \\
\hline & & Positive & 15 & 15.10 & & \\
\hline & & Ties & 18 & & & \\
\hline & \multirow{3}{*}{ TA to $\mathrm{pH} 5.5$ at T20 - TA to $\mathrm{pH} 5.5$ at T0 } & Negative & 21 & 14.33 & \multirow{3}{*}{-1.81} & \multirow{3}{*}{0.070} \\
\hline & & Positive & 8 & 16.75 & & \\
\hline & & Ties & 19 & & & \\
\hline & \multirow{3}{*}{ TA to $\mathrm{pH} 5.7$ at T20 - TA to $\mathrm{pH} 5.7$ at T0 } & Negative & 21 & 16.79 & \multirow{3}{*}{-2.05} & \multirow{3}{*}{0.040} \\
\hline & & Positive & 10 & 14.35 & & \\
\hline & & Ties & 17 & & & \\
\hline \multirow{9}{*}{$\begin{array}{l}\text { Regular } \\
(n=23)\end{array}$} & \multirow{3}{*}{ Endogenous $\mathrm{pH}$ at T20 - Endogenous $\mathrm{pH}$ at T0 } & Negative & 6 & 8.00 & \multirow{3}{*}{-0.74} & \multirow{3}{*}{0.458} \\
\hline & & Positive & 6 & 5.00 & & \\
\hline & & Ties & 11 & & & \\
\hline & \multirow{3}{*}{ TA to $\mathrm{pH} 5.5$ at T20 - TA to $\mathrm{pH} 5.5$ at $\mathrm{T} 0$} & Negative & 8 & 8.94 & \multirow{3}{*}{-1.20} & \multirow{3}{*}{0.232} \\
\hline & & Positive & 6 & 5.58 & & \\
\hline & & Ties & 9 & & & \\
\hline & \multirow{3}{*}{ TA to $\mathrm{pH} 5.7$ at T20 - TA to $\mathrm{pH} 5.7$ at T0 } & Negative & 10 & 6.50 & \multirow{3}{*}{-2.05} & \multirow{3}{*}{0.041} \\
\hline & & Positive & 2 & 6.50 & & \\
\hline & & Ties & 11 & & & \\
\hline \multirow{9}{*}{$\begin{array}{l}\text { All } \\
(n=71)\end{array}$} & \multirow{3}{*}{ Endogenous $\mathrm{pH}$ at T20 - Endogenous $\mathrm{pH}$ at T0 } & Negative & 21 & 23.36 & \multirow{3}{*}{-0.523} & \multirow{3}{*}{0.601} \\
\hline & & Positive & 21 & 19.64 & & \\
\hline & & Ties & 29 & & & \\
\hline & \multirow{3}{*}{ TA to $\mathrm{pH} 5.5$ at T20 - TA to $\mathrm{pH} 5.5$ at T0 } & Negative & 29 & 22.72 & \multirow{3}{*}{-2.25} & \multirow{3}{*}{0.024} \\
\hline & & Positive & 14 & 20.50 & & \\
\hline & & Ties & 28 & & & \\
\hline & \multirow{3}{*}{ TA to $\mathrm{pH} 5.7$ at T20 - TA to $\mathrm{pH} 5.7$ at T0 } & Negative & 31 & 22.81 & \multirow{3}{*}{-2.83} & \multirow{3}{*}{0.005} \\
\hline & & Positive & 12 & 19.92 & & \\
\hline & & Ties & 28 & & & \\
\hline
\end{tabular}


Table 4. Comparison of endogenous pH, titratable acidity (TA - mls of $0.1 \mathrm{M} \mathrm{NaOH}$ ) to pH 5.5 and 5.7 and $\mathrm{F}$ ion concentration (mg/L) of drinks based on their sugars content (Diet $\mathrm{v}$ Regular)

\begin{tabular}{|c|c|c|c|c|c|}
\hline Variables & Diet / Regular & $\mathbf{N}$ & $\begin{array}{l}\text { Mean } \\
\text { Rank }\end{array}$ & $\begin{array}{c}\text { Mann- } \\
\text { Whitney U }\end{array}$ & p value \\
\hline \multirow{2}{*}{ Endogenous $\mathrm{pH}$ T0 } & Diet & 48 & 44.40 & \multirow{2}{*}{149.00} & \multirow{2}{*}{0.001} \\
\hline & Regular & 23 & 18.48 & & \\
\hline \multirow{2}{*}{ Endogenous $\mathrm{pH}$ after T20 } & Diet & 48 & 44.75 & \multirow{2}{*}{132.00} & \multirow{2}{*}{0.001} \\
\hline & Regular & 23 & 17.74 & & \\
\hline \multirow{2}{*}{ TA to $\mathrm{pH} 5.5$ at $\mathrm{T} 0$} & Diet & 48 & 32.91 & \multirow{2}{*}{403.50} & \multirow{2}{*}{0.065} \\
\hline & Regular & 23 & 42.46 & & \\
\hline \multirow{2}{*}{ TA to $\mathrm{pH} 5.5$ at T20 } & Diet & 48 & 32.25 & \multirow{2}{*}{372.00} & \multirow{2}{*}{0.026} \\
\hline & Regular & 23 & 43.83 & & \\
\hline \multirow{2}{*}{ TA to $\mathrm{pH} 5.7$ at T0 } & Diet & 48 & 32.72 & \multirow{2}{*}{394.00} & \multirow{2}{*}{0.051} \\
\hline & Regular & 23 & 42.85 & & \\
\hline \multirow{2}{*}{ TA to $\mathrm{pH} 5.7$ at $\mathrm{T} 20$} & Diet & 48 & 32.34 & \multirow{2}{*}{376.50} & \multirow{2}{*}{0.030} \\
\hline & Regular & 23 & 43.63 & & \\
\hline \multirow{2}{*}{$\mathrm{F}$ ion concentration } & Diet & 48 & 36.52 & \multirow{2}{*}{527.00} & \multirow{2}{*}{0.754} \\
\hline & Regular & 23 & 34.91 & & \\
\hline
\end{tabular}


Table 5. Comparison of endogenous pH, titratable acidity (TA - mls of $0.1 \mathrm{M} \mathrm{NaOH}$ ) to pH 5.5 and 5.7 and $F$ ion concentration ( $\mathrm{mg} / \mathrm{L}$ ) of drinks based on container type (can v plastic bottle)

\begin{tabular}{|c|c|c|c|c|c|}
\hline Variables & Container type & $\mathbf{N}$ & Mean Rank & $\begin{array}{c}\text { Mann- } \\
\text { Whitney } \\
\text { U }\end{array}$ & p value \\
\hline \multirow{2}{*}{ Endogenous $\mathrm{pH}$ at $\mathrm{T} 0$} & Can & 23 & 40.89 & \multirow{2}{*}{393.50} & \multirow{2}{*}{0.083} \\
\hline & Plastic bottle & 46 & 32.05 & & \\
\hline \multirow{2}{*}{ Endogenous $\mathrm{pH}$ at $\mathrm{T} 20$} & Can & 23 & 41.26 & \multirow{2}{*}{385.00} & \multirow{2}{*}{0.065} \\
\hline & Plastic bottle & 46 & 31.87 & & \\
\hline \multirow{2}{*}{ TA to $\mathrm{pH} 5.5$ at $\mathrm{T} 0$} & Can & 23 & 29.85 & \multirow{2}{*}{410.50} & \multirow{2}{*}{0.128} \\
\hline & Plastic bottle & 46 & 37.58 & & \\
\hline \multirow{2}{*}{ TA to $\mathrm{pH} 5.5$ at T20 } & Can & 23 & 29.30 & \multirow{2}{*}{398.00} & \multirow{2}{*}{0.093} \\
\hline & Plastic bottle & 46 & 37.85 & & \\
\hline \multirow{2}{*}{ TA to $\mathrm{pH} 5.7$ at $\mathrm{T} 0$} & Can & 23 & 30.87 & \multirow{2}{*}{434.00} & \multirow{2}{*}{0.222} \\
\hline & Plastic bottle & 46 & 37.07 & & \\
\hline \multirow{2}{*}{ TA to $\mathrm{pH} 5.7$ at T20 } & Can & 23 & 30.46 & \multirow{2}{*}{424.50} & \multirow{2}{*}{0.180} \\
\hline & Plastic bottle & 46 & 37.27 & & \\
\hline \multirow{2}{*}{$\mathrm{F}$ ion concentration } & Can & 23 & 36.17 & \multirow{2}{*}{502.00} & \multirow{2}{*}{0.726} \\
\hline & Plastic bottle & 46 & 34.41 & & \\
\hline
\end{tabular}

